\title{
Preliminary Observations on the Transpiration Current in Submerged Water-plants.
}

\author{
BY \\ D. THODAY, M.A., \\ Trinity College, Cambridge, Mackinnon Student of the Royal Society.
}

AND

M. G. SYKES,

Girton College, Fellow of Nerwnham College, Cambridge.

THE growing tendency to doubt whether known physical forces are 1 sufficient to bring about the ascent of water in tall trees, and to look to the agency of living cells adjacent to the conducting channels to supplement them, has suggested to us that the water current in submerged waterplants might be worth investigation. In this case evaporation from the leaves, an essential link in the chain of physical factors in the transpiration of land plants, is eliminated.

Experimental evidence for the existence of a transpiration current in water-plants has been brought forward by Sauvageau, ${ }^{1}$ Hochreutiner, ${ }^{2}$ Pond, ${ }^{3}$ and others. Hochreutiner, by using a solution of eosin, obtained values for the rate of the current in cut branches of Potamogeton pectinatus, $P$.crispus, $P$. densus, and Ramunculus aquatilis, but his experiments were of many hours' duration, and the eosin travelled not more than half a centimetre per hour.

A similar eosin method was employed in some experiments with Potamogeton lucens, which were made by a class of students superintended by one of us during a course of demonstrations on the physiology of plants given in the laboratory of the Royal Holloway College. A glass cylinder was divided into two portions by a closely fitting flat cork covered with a soft wax mixture. The lower chamber was filled with a dilute solution

1 Sauvageau: Feuilles des Monocotylédones aquatiques. Ann. des Sc. Nat., Bot., sér。 7, xiii, I89I, p. I03.

2 Hochreutiner, G. : Études sur les Phanérogames aquatiques du Rhône et du Port de Genève. Rev. Gén. de Bot., viii, I 896 , p. I 58 .

3 Pond: The biological relation of aquatic plants to the substratum. Contributions to the biology of the Great Lakes, 1905.

[Annals of Botany, Vol. XXIII. No. XCII. October, 1909.] 
of eosin, the plant stem firmly fixed by means of cotton wool in a hole bored in the cork, and the rest of the cylinder filled with water so that the branch was completely submerged. The eosin was observed to penetrate at rates considerably greater than those recorded by Hochreutiner, the maximum being $10 \mathrm{~cm}$. in $4 \frac{1}{2}$ hours. This suggested to us that experiments in sitz might be interesting, for although the material was handled as carefully as possible it could not, from the nature of the method, be kept submerged during the short interval occupied in setting up the experiment.

Experiments were therefore made with plants of $P$.lucens, growing in the river Cam, during July and August of this year. The method adopted was to attach a small glass bulb of eosin to the cut end of a submerged branch. A good leafy stem was chosen, cut under water, and left submerged for a short time. A little cotton wool was then wrapped round the stem near the cut end, a small bulb of eosin brought down to the surface of the water, and the cut end lifted for a moment above the surface and inserted in the bulb. When the experiment was of short duration the stem was merely held under water, but when a longer time was required it was attached at two or three points to a bamboo float and kept beneath the water by one or two small strips of lead bent round it. At the end of the experiment the bulb was removed and the stem at once examined.

The rate of transmission of the eosin solution was found to be surprisingly rapid. The earlier experiments lasted from fifteen to five minutes, and in each case the eosin was found to have travelled up to the apex, a distance of 20 to $30 \mathrm{~cm}$. The times of experiment were then reduced; the appended table gives a number of the results so obtained for the rate of flow of the eosin.

\begin{tabular}{|c|c|c|c|c|}
\hline Time. & $\begin{array}{c}\text { Duration of } \\
\text { experiment in } \\
\text { minutes. }\end{array}$ & $\begin{array}{c}\text { Number of } \\
\text { internodes traversed } \\
\text { by eosin. }\end{array}$ & $\begin{array}{c}\text { Total length } \\
\text { traversed by } \\
\text { esin, in cin. }\end{array}$ & $\begin{array}{c}\text { Rate of flow } \\
\text { in centimetres } \\
\text { per minute. }\end{array}$ \\
\hline 8.15 p.m. & $\mathrm{I}$ & $2 \frac{1}{3}$ & 5.7 & 5.7 \\
8.28 p.m. & $\mathrm{I}$ & 1 & 7.5 & 7.5 \\
II.0 a.m. & 2 & 4 & 19.0 & 9.5 \\
7.53 p.m. & 2 & $2 \frac{1}{2}$ & 14.0 & 7.0 \\
4.52 p.m. & 3 & 7 & 17.5 & 5.8 \\
I2.23 p.m. & 3 & 4 & 18.2 & 6.1 \\
\hline
\end{tabular}

The results are found to depend largely on the state of the material employed, and such high results as those given in the table were only obtained with healthy branches. Probably external conditions also affect the results; this point we hope to investigate later. It was not found that the length of time which elapsed between the cutting of the stem and the immersion of its cut end in eosin had any appreciable effect on the result of the experiment. 
We also hope by further experiments to obtain some light on the mechanism of the rapid water current in $P$. lucens, and in other submerged water-plants. Some preliminary experiments have indicated that it depends principally on the leaves:

I. When the apex of a detached stem was removed the eosin entered from below more slowly than before, in one case $4.5 \mathrm{~cm}$. in three minutes. When the bulb of eosin was affixed to the upper cut end a very slow current was observed in the reverse direction. In one experiment it was found that after eight hours the eosin had travelled backwards throughout the length of the detached stem employed. In two other experiments, lasting three minutes the eosin had traversed a distance of about $2 \mathrm{~cm}$. When bulbs of eosin were attached to both cut ends, the eosin penetrated slowly from each end.

The possibility of a reverse current suggests that the normal current depends at most only to a very small extent on the stem itself.

2. That, on the other hand, the leaves are the determining factors is indicated by experiments in which some or all of the leaves were removed. When all the leaves and the apical bud were cut off the current in the upward direction was extremely slow, e.g. in one experiment, $3 \mathrm{~cm}$. in thirty-two minutes. In the backward direction the eosin had not penetrated at all at the end of an experiment lasting eight hours. When some of the leaves were removed, the current was diminished roughly in proportion to the number removed. For instance, in an experiment in which about half the leaves were removed the rate of transmission of the eosin was $3 \mathrm{~cm}$. per minute as compared with $6 \mathrm{~cm}$. in a control experiment with a similar branch.

On anatomical and experimental grounds, Sauvageau, ${ }^{1}$ Weinrowsky, ${ }^{2}$ and Max v. Minden ${ }^{3}$ point to special apical 'pores' as organs of exudation. From experiments in which the tips of the leaves were removed these do not appear to be active, as the results showed no appreciable diminution in the current; but we do not regard these experiments as conclusive.

In conclusion, our experiments have shown

I. An unexpectedly rapid water current in detached rootless stems of Potamogeton lucens;

2. That this current is at any rate largely dependent on the leaves.

$$
\begin{gathered}
\text { Botany School, Cambridge, } \\
\text { August, igog. }
\end{gathered}
$$

1 Sauvageau, 1. c.

2 Weinrowsky, P.: Untersuchungen über die Scheitelöffnungen bei Wasserpflanzen. Bot. Centralbl., Beihefte, ix, 1900 , p. 176.

${ }^{3}$ Minden, Max vo: Beiträge zur anatomischen und physiologischen Kenntniss wassersecernierender Organe. Inaug。-Diss., Bonn, I 898 . 


\section{$2 \mathrm{BHL}$ Biodiversity Heritage Library}

Thoday, David and Sykes, Mary Gladys. 1909. "Preliminary observations on the transpiration current in submerged water-plants." Annals of botany 23, 635-637. https://doi.org/10.1093/oxfordjournals.aob.a089245.

View This Item Online: https://www.biodiversitylibrary.org/item/236540

DOI: https://doi.org/10.1093/oxfordjournals.aob.a089245

Permalink: https://www.biodiversitylibrary.org/partpdf/318980

\section{Holding Institution}

Smithsonian Libraries

\section{Sponsored by}

Biodiversity Heritage Library

\section{Copyright \& Reuse}

Copyright Status: Not in copyright. The BHL knows of no copyright restrictions on this item.

This document was created from content at the Biodiversity Heritage Library, the world's largest open access digital library for biodiversity literature and archives. Visit BHL at https://www.biodiversitylibrary.org. 